\title{
The Training Pattern of Undergraduate Application-Oriented Talents for Tourism Management in Local Colleges
}

\author{
Minggui Cao \\ School of Business Management \\ Xinyang Normal University \\ Xinyang, Henan \\ Cmg68@163.com
}

\begin{abstract}
With the rapid development of the tourism industry, shortage of talents followed, and training of application-oriented talents is imminent. This paper outlines some of the related problems for Applicationoriented talent training: the talent training objectives are homogenize; the talent training and industry demand is not consistent; The curriculum is not reasonable; the teaching methods are obsolete and high quality teachers are in short. To train application-oriented talents with multiple levels, dimensions and dimensions, the author suggests developing proper talent training objectives, making the market-oriented training plans, presenting curriculum for training application-oriented talents, changing the obsolete teaching methods, and strengthening the cooperation between colleges and enterprises.
\end{abstract}

Keywords—tourism management; application-oriented talents; training model; undergraduate talents

\section{INTRODUCTION}

With the rapid development of tourism industry, tourism talents, especially those suitable for tourism development, is in shortage, the cultivation of tourism talents is highly valued, which puts forward the new requirements for undergraduate application-oriented talents for tourism management[1].

\section{THE BASIC CHARACTERISTICS OF APPLICATION-ORIENTED TALENTS}

Due to the special nature of the tourism industry, the objectives for training tourism management applicationoriented talents are also have different from others, the basic characteristics are listed as follows:

\section{A. Comprehensive}

As we know, tourism products are mainly intangible service, hence the service relies on the staff to complete, and services cannot be stored, beside, the production and consumption cannot be separated, so for tourism enterprises, one of the key factors for the success is direct connection with the staff[2]. Therefore, the tourism management should have strong business ability, solid professional knowledge and profound humanistic moral knowledge.

\section{B. Availability and Practicability}

The traditional industry mainly focus on the relationship between man and nature, while compared with the traditional industry, tourism is to provide valuable services for the people, to deal with the relationship between natural science and Humanities \& social science, which requires availability and practicability for training application-oriented talents[3].

\section{Adaptability}

In nowadays, changes are constantly taking place in the demands of tourism market, thus the tourism industry has to be developed and updated for sustainable development. The tourism staffs need to master many kinds of knowledge, and adapt to the job, they also need strong ability for innovation and continuous learning, then adapt to the development of the tourism industry.

\section{International}

The development of economic globalization brings both opportunities and challenges, and put forwards higher requirements for talent training of tourism industry[4], in addition to have a solid theoretical knowledge, operational skills and communication skills, the staffs also need to understand the domestic \& foreign politics, history, economics, the emerging e-commerce technology and so on.

On this basis, the basic characteristics of tourism applied talents shows in three aspects:

First of all, they should have multi-level knowledge structure. The basic principle for training applied talents is "thick foundation, wide scope", students should focus on theoretical knowledge and develop the ability of adapting to work. The tourism relates to economics and management, beside, also involves other disciplines such as history, geography, architecture and so on. In the knowledge structure, history, geography and other disciplines are also necessary beyond relevant economics and management.

Secondly, the ability should be multi-level. The application-oriented talents cultivation should aim at basic level management, focus on training of professional basic knowledge and the application ability. In addition, it is also 
necessary to cultivate the professional knowledge and skills of innovation, creativity, and the ability to start a business.

In the last, the quality should be multi-dimensional. Tourism mainly dependents on staff to provide services, the quality of practitioners is directly related to the quality of the service. For application-oriented talents, they should have high professional quality, beside, professional thinking and ethics are also essential for the customer service. All of the qualities play a decisive role in the quality of service.

\section{PROBLEMS IN APPLICATION-ORIENTED TALENTS Cultivation}

\section{A. Talent Training Objectives are Homogenize}

At present, we take into account the cultivation of students' professional ability and the moral qualities for tourism management talents training, however, the cultivating target is quite fuzzy, there is no emphasis in the training process, professional practice and application are not reflected, and students are kind of too extensive rather than specialized, which result to lack of profession, then after graduation, the students cannot meet the requirements of tourism enterprises. For Colleges and universities, when making the training target, they blindly model the research university without considering actual situation, the colleges pay too more attention to the students' academic research, but ignore the fundamental practical skills, which result in personnel training plans of each levels are similar. As to tourism, it is difficult to take in so many tourism employees at the research level, and then there comes a great mismatch between the demand and the talent training[5].

\section{B. Talent Training and Industry Demand is not Consistent}

On the one hand, with the development of the tourism industry, the tourism has not only limited in the traditional travel agencies, hotels and scenic spots, there should be more, such as the integration of internet and other industries. But unfortunately, the professional curriculum settings often limited to the traditional way, even the travel and transportation rarely involved, not mention emerging exhibition industry and tourism e-commerce. Hence professional settings cannot keep up with the pace of development of the tourism industry, and It is difficult for the students to be qualified for the development of the tourism industry; On the other hand, although theoretical knowledge of the tourism management undergraduates is solid, but their experience is extremely scarce, which make them unable to meet the needs of enterprise. Beside, the expectations for the undergraduate is not high, resulting in a serious mismatch between the demand and the training, which lead to a serious lack of special talents of middle-high level, and ultimately restrict the development of Tourism[6].

\section{The Curriculum is not Reasonable}

At present, many colleges set the curriculum only according to their own situation, even more, some colleges blindly model other universities, they did not set the curriculum according to the actual needs of the tourism industry. Beside, many schools offer courses without proper standardization, there is lack of transition and connection between courses, thus the subject characteristics cannot be reflected[7]. On one hand, The current tourism management curriculum are in favor of theories, such as economic management, but the courses for professional practice and operation are in short. The tourism industry requires the staffs not only have a solid theoretical foundation, but also have operational skills. Then the curriculum has departed from tourism' actual development, which resulted the students can't find proper job when they graduate. On the other hand, the courses are not applicable, the colleges cannot make timely adjustment and update the curriculum, hence unable to adapt to the development of tourism industry.

\section{The Teaching Methods are Obsolete}

At present, the teaching mode of Tourism Management in our country is mainly center around teachers, classroom, explanation and teaching material. The traditional teaching mode makes the teacher occupying the center position, teachers and students is a one-way transmission relationship, students learn whatever teachers teach, as a result, the students cannot get proper guidance and training for self-learning ability, which make it difficult to develop independent thinking for students[8].

\section{E. High Quality Teachers are in Short}

Generally speaking, there are two kinds of professional teachers in tourism management: the first kind is those with the background of tourism management, most of them have master degree or bachelor degree, There are very few PHD, the lack of PHD teachers seriously restricts the improvement of teaching quality. The second kind are those with other backgrounds, such as history, geography, economic and other related disciplines, those teachers do not have experience of tourism management, then it is very difficult for them to become leaders in the professional field. Beside, most professional teachers begin their career just after graduation, many of them are lack of practical experience and work experience, they don't have good understanding for recent tourism developments, which resulting in teaching theory is separated from practice, then unable to meet the needs of the development of the tourism industry.

\section{CONSTRUCTING THE UNDERGRADUATE APPLICATION ORIENTED TALENTS}

\section{A. Making Talent Training Objectives in Line with Their Own Development}

When making the personnel training objectives, the colleges need to consider the requirements of tourism enterprises, combine with their own actual situation, and then customized talents training objectives for tourism enterprises. The colleges should attach great importance to the development of students' ability, make full use of educational resources and maximize their advantages, form their own college-running feature, so that correspond personnel training goal to tourism development. 


\section{B. Making the Market-Oriented Training Plans}

In order to make applied talents training plan for tourism management undergraduate, the colleges should aim at the needs of the tourism market, relate to the development of the tourism industry and enterprises, and consider the needs of the employing market. In addition to theory courses, the colleges also need to pay attention on practice and the training of practical skills, beside, make full use of practice base to enrich the students' practical experience. Meantime, professional setting should keep in step with the development of the industry changes, and set the division of professional direction in accordance with the current market demands, then provide the needed talents for tourism.

\section{Training Application-Oriented Talents}

In order to train applied talents, the colleges need to highlight its application characteristics, and pay more attention to its application ability while value students' theoretical basis at the same time. theoretical courses and practical courses, both hands to grasp for curriculum. It is important to highlight the students' ability of finding, thinking and solving, the students' training of self cognition, self control, and logical analysis ability should be integrated into the teaching process, hence strengthening the students' professional quality. In addition, it also necessary to pay attention to the scope of the curriculum and the cohesion of related courses, update and delete the courses according to the development of tourism, then unified curriculum system[9].

\section{Changing the Obsolete Teaching Methods, Strengthening the Cooperation Between Colleges and Enterprises}

The teachers should change the teaching method of spoonfeeding students, guide the students and highlight the ability of finding, thinking and solving, in addition to the traditional teaching, the teachers should explore new teaching methods, such as blogging and micro channel platforms to interact with the students at anytime and anywhere, and introduce micro lesson into teaching, in order to modernize teaching methods and teaching content. Secondly, it is necessary to strengthen cooperation with enterprise, the colleges should invite industry leader and enterprise managers to go to the classroom beside establishment of long-term stable practice bases, as a result, the industry related experience can be taught to students, hence shorten the adaptation period and raised the employment rate.

\section{E. Strengthening the Construction of Teaching Staff}

In order to adapt to the requirements of the teaching for tourism management, the teachers should keep contact with the tourism, implement continuing education and post training, and make them obtain the practical experience, then improve the overall level of the teachers. At the same time, the colleges should increase the training of "double type" teachers[10], it is necessary for teachers to obtain the relevant qualifications. it is also helpful to set up part-time teachers and employ industry experts as part-time professors except for full-time teachers, invite the outstanding staffs as a part-time teacher, ask them to teach experience and industry related knowledge to the students, then make it clear for the students about business requirements in order to avoid the employment difficulties.

\section{ACKNOWLEDGMENT}

I would like to express my gratitude to all those who helpe $\mathrm{d}$ me during the writing of this thesis. This paper is for Major Teaching Reform Research Project of 2015 Xinyang Normal College: Research and practice on the reform of applied talents training system in local colleges and universities for tourism management; the stage research results of specialty construction in Henan province.

\section{REFERENCES}

[1] Gardner.H, "Intelligences Reframed:Multiple Intelligences for 21st Century,” NewYork:Basic Book,1999.

[2] CHEN Xiangjun,SUO Kaifeng, "Discussion on the Pattern of the Talent Cultivation of Application-oriented Undergraduate Education of Economic Management Specialty,” Education and Teaching Research;2009-12

[3] WANG Xiao-gang,FENG Wei, "The Practical Teaching in Road Engineering Cost Program in Vocational College,” Journal of Guangdong Communications Polytechnic;2013-01

[4] FENG Wei,WANG Xiao-gang, "A Research on Integrated Teaching in Highway Engineering Cost Course,’Journal of Guangdong Communications Polytechnic;2013-02

[5] LI Bo,YANG Qiong, “On the Contest for College Students and the Cultivating of Innovative Talented People,’The World and Chongqing;2013-11

[6] Cai Huaihong,Meng Jianxin,Yang Peihui,Cao Liwei,Zhou Yanhui, and Chen Cuijuan, "Teaching Reformation and Practice for Cultivation of Application-oriented Talents: Analytical Chemistry Experiments," Guangdong Chemical Industry;2014-01

[7] HAN Bang-xing,and CHEN Nai-fu, “Analysis on Culture Mode of Local Applied Talents,”Journal of Anhui Agricultural Sciences;2014-12

[8] TIAN DA-yong,ZHEN Yong,and YAN Dong, "The Educational Reform of Environmental Impact Assessment under the Talent-Training Model of Applied Undergraduate,”Journal of Anyang Institute of Technology;2014-04

[9] JIANG Zilian,ZHANG Shiping,LIAN Yong, and GUO Haihua, "Curriculum Reform of Mechanical Engineering Materials and Heat Treatment in Newly-built Application-oriented Universities,”Journal of Chengdu Technological University;2014-03

[10] WU Xiao-jing, "Macintyre's View of Practice on the Cultivation of Applied Talents Inspiration,’Higher Education Forum;2014-10 